\title{
The Ontological Spiral: Virtuosity And Transparency In Mongolian Games
}

\author{
KATHERINE SWANCUTT
}

University of Oxford

katherine.swancutt@anthro.ox.ac.uk

Playing 'The Stag' is not difficult. It's easy. You look and immediately know where to go [with your pawns]. If he comes in this direction, then I go there. If I eat him or if he traps me, then this is a straightforward result. It is not due to where my fortune stands. The necessary move is obvious.

- Züün Sum's local champion of 'The Stag'

\begin{abstract}
Bodily affects, in Viveiros de Castro's sense of the term, are not just physical characteristics, such as the comportment, mannerisms or tastes consistently ascribed to a given subject. They are also 'forces', 'energies' or 'talents' which are taught, acquired and refined over time. This article argues that virtuosity and fortune are bodily affects which Mongols hold to varying degrees. Through the Mongolian game called 'The Stag', the article shows how players refine their virtuosity affect while receiving sudden influxes of fortune. Virtuosi and novice game players exchange perspectives in the pedagogy of play, travelling along an 'ontological spiral' of knowledge which renders the winning moves transparent.

Additionally, the article shows that Mongols occasionally conflate bodily affects with their interior spiritual quality. Mongol notions of ownership typically allow that animals and personal effects are (1) subjects unto themselves or (2) the bodily affects of their owners, which propagate their owners' distributed personhood or spirithood. But when playing Stag, Mongols can simultaneously refine their virtuosity (promoting intra-species differences) while adopting animal affects (crossing the interspecies divide). Given this, the article proposes a 'Mongolian perspectivism' where people, spirits and animals can shift subjectivity at both the intra-species and interspecies levels. The theory of perspectivism is more responsive to fluctuations in bodily affects and interior spiritual qualities than has been anticipated, making it open to radical refinement.
\end{abstract}

Keywords: games, virtuosity, fortune, pedagogy, perspectivism, intra-species, aleatory point 


\section{VIRTUOSITY AS AN AFFECT}

There is good reason why Viveiros de Castro's theory of perspectivism has been consistently demonstrated through the virtuoso's point of view. Only virtuosi, such as shamans, great hunters, game champions or performing artists have the trained ability to readily manoeuvre between different viewpoints or 'perspectives' (Viveiros de Castro 1998: 471-2, see also 483 and 2004: 468-9). Viveiros de Castro has ascribed a highly specific mode of being to his notion of perspectivism, which arises from a basic discrepancy. All 'subjects' (usually defined as humans, spirits and animals) share the same 'interior spiritual quality', such as a soul (Pedersen 2001: 414). But different kinds of subjects - such as a person and a jaguar - have different bodily 'affects', that is, different physical builds, comportment, mannerisms, senses, forces, energies, etc. which may be characterised as exterior 'clothing' (Viveiros de Castro 1998: 482, 1998a: 4, 2004 : 474-5). Every subject's point of view, or perspective, is part of an overall totality of the self, comprised of an interior spiritual quality (shared by all subjects) and a 'bundle of affects and capacities' (specific to different kinds of subjects; Viveiros de Castro 1998: 478). When two different subjects meet, their shared spiritual quality makes it possible for one of them to identify with the other, and thus adopt his or her perspective. Changes in perspective are total, taking place at the level of interior spiritual quality and bodily affects. Shifting perspectives, then, means adopting the other's complete selfhood.

Such a dramatic shift in perspective is not common. As Viveiros de Castro points out in a well-known passage: 'Typically, in normal conditions, humans see humans as humans, animals as animals and spirits (if they see them) as spirits...' (1998: 470). Different subjects often simply take note of one another's presence, without interacting on a close enough level to make possible a shift in perspective. To give some present-day examples, Buryat Mongol shamans may divine without the assistance of the spirits, simply reading their implements without taking on the spirit's perspective (Swancutt 2006: 339-46). Or Amazonian hunters may come into close range for a kill, without paying any heed to the dangers of adopting their prey's perspective, so that 'they just shoot it dead, [considering that] it's just a damn jaguar' (Hugh-Jones 2004). Changes in perspective do not happen automatically, just because subjects with different perspectives happen to meet. More substantial interaction is necessary. A change of perspective arises where different subjects, through their interaction, find that one party's perspective was powerful enough to have overwhelmed the other. For instance, when a Buryat Mongol shaman invokes his ancestral spirits to travel from the heavens to his home, contact with those spirits may be overwhelming to the shaman. The shaman may be possessed by a particular spirit before the invocations are complete, donning that spirit's affects and perspective, including the spirit's biography, level of virtuosity, movements, mannerisms, cravings and outlook on the human world as a 'thing of air' (khii yüm) which resides in the heavens (tenger). Since changes in perspective occur where subjects share the 
same interior spiritual quality (both Buryat shamans and spirits have souls), this shift in perspective can be traced to a difference in bodily affects. As these two subjects' viewpoints 'reverberate' off of each other, the spirit's bodily affects overwhelm the shaman's affects and both parties come to hold the same viewpoint. Accordingly, subjects never impose their perspectives, single-handedly, onto the world around them. Contrasting Western naturalism with Amazonian perspectivism, Viveiros de Castro sums up how, in perspectivism, the point of view creates the subject:

Whilst our constructionist epistemology can be summed up in the Saussurean formula: the point of view creates the object - the subject being the original, fixed condition whence the point of view originates - Amerindian ontological perspectivism proceeds along the lines that the point of view creates the subject; whatever is activated or 'agented' by the point of view will be a subject (1998: 476-7).

Shifts in perspective often arise in response to hostility or as unwitting reactions to, say, the fright an Amazonian has when coming across an animal in the forest and failing to recognise whether his, or the animal's, affects are properly his own (Viveiros de Castro 1998: 481). Perspectival shifts can potentially trigger an irreversible metamorphosis. Siberian hunters thus keep dangerous perspectives at a distance, oscillating between their own viewpoint and that of the prey animal (Willerslev 2004: 630, see also 639-47). But whether considered in terms of donning, deflecting or oscillating between viewpoints, perspectivism hinges upon the idea that virtuosi, such as shamans, increasingly gain skill in handling different viewpoints (even if that virtuosity is aided by hallucinogenic drugs). Virtuosity in any given practice qualifies as a bodily affect: it arises from a trained, internalised skill that is both physical-habitual and accessible to reflection in the mind (see the discussion of pedagogy below). I use the terms 'virtuosity' and 'virtuoso' in a general sense, including within their remit any selfhood produced through elite training (e.g. a Mongol game champion, shamanic ancestral spirit or racehorse). This notion of virtuosity is not incompatible with the view that perspectivism can be more than 'an abstract model', providing an explanatory basis for 'real experiences of people in a life world' (Willerslev 2004: 630). For as this article shows, players continually shift perspectives in the Mongol game called 'Stag', as part of the lifelong process of refining their 'virtuosity affect'.

\section{RECIPROCAL TRAINING: THE VIRTUOSO AND THE NOVICE}

Let us begin with an outline of the pedagogical relationship between virtuosi and novices - which, as we will see, is reciprocal - and link this to perspectivism. The virtuoso-novice relation was apparent throughout one month's fieldwork (September-October 2005) that I carried out among Deed Mongols in the district of Züün Sum (Chinese: Zongjia), Qinghai Province, north-west China. ${ }^{1}$ Virtuosi 
of any discipline in Züün Sum start out as novices, being introduced to a given craft by kin, mentors or peers at school, as is commonly the case with the game of Stag. Players often acquire skill by imitating other players, attempting to internalise their skills and viewpoints. At a later stage, players may also train themselves through self-imposed corrections, made in light of what they have learned to regard as the virtuosic perspective. Just as learning a skill requires ongoing effort from the novice (who must keep practising to acquire, refine and later maintain the virtuoso's perspective), the virtuoso must take on the comparatively narrow perspective of the novice to teach effectively. How else can the virtuoso perceive the stumbling blocks to the novice's learning and, aware of those faults, teach his or her pupil to overcome them?

Both the process of learning virtuosity as a novice and the virtuoso's efforts at backtracking to the novice's perspective are difficult. Neither player can stop short with mere self-reflection or guesswork if they are to teach and acquire skill. Pedagogy requires actual shifts of perspective between virtuoso and novice, through the mode of collaborative instruction which we call 'apprenticeship'. Deed Mongols say that games are played in the effort to train one's mind ( $u k h a a$ n'zaakh), including through the instruction of mentors. When virtuosi and novices work together - as in the game of Stag where training takes place through competitive play - their points of view collide. This collision of viewpoints can cause either the virtuoso or novice to be taken over by the other's perspective. Indeed, Deed Mongols say that people play games to learn the art of war (dain), where actual collisions arise between opponents and their viewpoints.

Each shift of perspective moves players along what I call an 'ontological spiral' of pedagogy, through which players accumulate knowledge, such that virtuosic manoeuvres becomes increasingly transparent (Figure 1). This is not to say that the virtuoso permanently reverts to the lower level of knowledge he had when he was a novice. Nor does the novice become a virtuoso by momentarily swapping perspectives with him. The pedagogical swapping of perspectives is only temporary, such that both parties return more-or-less to their respective states of being, with only incremental changes to the knowledge and affects that these entail. However, each instance of swapping perspectives does help players broaden their awareness of the different vantage-points from which winning moves are made. Eventually, this shifting of perspectives leads players to significantly refine their virtuosity affect and reach a new ontological 'endpoint' in their personhood (they obtain a higher level of virtuosity, which is maintainable through training). Like the return of the mother's brother in the Melanesian ritual of Naven - famous in anthropology because it demonstrates that shifts in perspective bring about long-term changes in personhood-Mongol virtuosi and novices take on different pedagogical roles to obtain different states of subjectivity (Bateson 1936: 74-85). ${ }^{2}$

I use the term 'pedagogy' in a general sense (not just referring to explicit instruction in the classroom or didactic settings), as when we consider that even two chess virtuosi 'learn from each other' through informal practice and champi- 


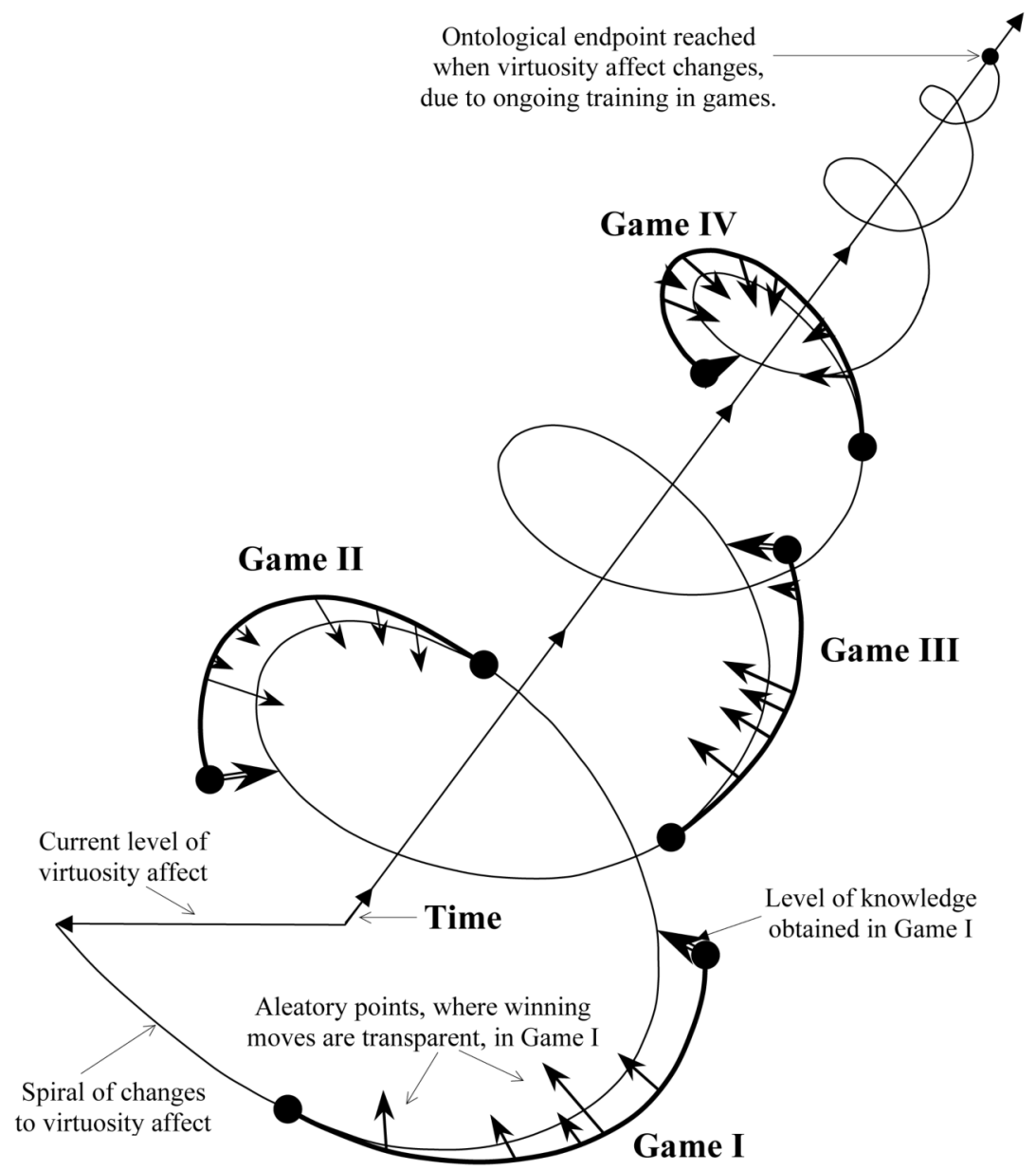

FIGURE 1. The ontological spiral through which game players refine their virtuosity affect.

onship matches alike. Pedagogy is a useful concept to my argument because it shows that (1) learning a skill instils different degrees of virtuosity in people and (2) bodily affects can change over time. Different kinds of people are created through different degrees of virtuosity. Even an accomplished chess player is not the same as a chess virtuoso. Both players share the same interior spiritual quality (e.g. a soul and an understanding of chess), but these players have different affects since the winning moves are more transparent to the virtuoso than the accomplished player. Of course, accomplished players may become virtuosi with continued practice, but this actually underscores my point that virtuosi and nonvirtuosi are different kinds of people (making for an 'intra-species' difference). 
Only the greatest virtuosi, through years of learning gaming moves, may naturally perceive the world as, say, a chessboard, across which everything moves like chess pieces. Consider Nabokov's protégé, whose chess-ridden perspective eventually drives him to suicide in The Luzhin Defense:

That day Luzhin junior was in low spirits. All the games in the old magazine had been studied, all the problems solved, and he was forced to play with himself, but this ended inevitably in an exchange of all the pieces and a dull draw. And it was unbearably hot. The veranda cast a black triangular shadow on the bright sand. The avenue was paved with sunflecks, and these spots, if you slitted your eyes, took on the aspect of regular light and dark squares. An intense latticelike shadow lay flat beneath a garden bench. The urns that stood on stone pedestals at the four corners of the terrace threatened one another across their diagonals. Swallows soared: their flight recalled the motion of scissors swiftly cutting out some design (2000 [1964]: 59-60).

Virtuosity is, then, like any other bodily affect: it is a building-block within, or a fundamental component of, a person's perspective. According to Viveiros de Castro's idea that the point of view makes the subject, no person can wilfully put his own affects, let alone his perspective, at a distance from himself. Thus, like all game players, the character Luzhin cannot separate his virtuosity from himself. If a chess protégée generates fictitious players in his own mind, he will find those players to be unworthy opponents who cannot present any unexpected moves. Fictitious opponents created in an ideal game of the mind only play our own perspectives back on ourselves, leading to Luzhin's dull draw. To play against a different perspective, a person must engage in actual play with a different subject, coming into contact with that subject's point of view and bundle of affects. Those affects may belong to a computer with an all-too-predictable program, but because the computer is a different subject, it will generate a perspective different to one's own.

\section{INTRA-SPECIES VARIATION}

This section presents Mongol notions about interior spiritual qualities and bodily affects - especially virtuosity and fortune (khiimor') - which are fundamental to Mongol games and commonly give rise to intra-species perspectivism. Viveiros de Castro has shown that Amazonians also recognise intra-species differences, since Amazonian shamans use their shamanic virtuosity to take on animal and spirit perspectives, whereas ordinary people only shift perspectives accidentally (1998: 472, see also 483). More generally, Amazonian people and other beings also have varying degrees of bodily affects:

[p]ersonhood and 'perspectivity' - the capacity to occupy a point of view - is then a question of degree and/or context [...] rather than an absolute, diacritical property of some species and not of others. Some non-human beings evince this attribute in a more consequential manner than others; as a matter of fact, many of 
them have powers of agency far superior to humans and in this sense are 'more persons' than the latter (1998a: 9).

Intra-species differences are, however, more pronounced among Mongols. Unlike Amazonians, Mongols do not consider that all 'animals have a human, sociocultural inner aspect that is "disguised" by an ostensibly bestial bodily form' (Viveiros de Castro 2004: 465). Nor do Mongols attribute all animals with culture (e.g. kinship, organised residence, etiquette, rituals). Due to their imperial past (Pedersen 2001: 411), Mongols relate to their fellow humans, animals and the spirits in a comparatively more hierarchical way than do the Amazonian forest groups described by Viveiros de Castro. A link can thus be drawn between Mongol hierarchy, specialised training (e.g. to become shamans or game players) and a markedly uneven distribution of bodily affects at the intra-species level. For example, Mongol laypersons are separated from shamans, who use their virtuosity affect to adopt the perspectives of human ancestral spirits (ongon orokh; Pedersen 2007: 158-9; Hamayon 1996: 81-5; Mikhailov 1987: 9-32; Galdanova 1987: 65-7), while Daur Mongol shamans take on the perspectives of both human and animal spirits (Humphrey with Onon 1996: 185-93). Hierarchies also pervade the Buryat shamanic spirit world, since the spirits obtain different levels of virtuosity during their lifetimes (Swancutt 2006: 346-7). Buryat shamanic training is sometimes even carried out after death, in the spirit world.

Pedersen regards Buryat spirit possession as an example of 'inter-human perspectivism (humans becoming other humans)' specific to the 'Southern North Asian' region (2001: 421). He points out that Buryat spirits - who are the spirits of deceased shamans - were human when alive and retained this human interior spiritual quality after death (2001: 423). But Buryats consider that at death, shamans become distinctly non-human, when changing at the level of bodily affects into 'things of air' (khii yüm). Generally, Buryat spirits reside in the shamanic afterlife world and only don human affects when possessing shamans. Thus, Buryat spirit possession is actually a kind of interspecies perspectivism (shamans adopt the perspectives of spirits who share their interior spiritual quality but differ in bodily affects). Still, Pedersen's idea of inter-human perspectivism tallies with the broader argument I make about intra-species perspectivism, where virtuosic training produces different kinds of Mongol spirits (high-ranking shamanic spirits vs. ordinary shamanic spirits), humans (virtuosic game players vs. novices) or animals (racehorses vs. ordinary horses).

Any Mongol, layperson or shaman, may shift perspective at the intra-species level, becoming a different type of person when losing or recovering their souls (süns) or spirits (sür süld). Souls and spirits qualify as both bodily affects - influencing health, happiness and well-being - and they are also elements of a Mongol's interior spiritual quality (Swancutt in press and 2003; Højer 2004; Pedersen \& Højer forthcoming). Mongols also undergo perspectival shifts when viewing photographic 'montages' in their own and other people's homes, which 
exhibit different levels of kin relatedness, and thus, different kinds of personhood (Empson 2007: 129-34). Finally, Mongols become different kinds of people when their bodily affect of 'fortune' fluctuates. The term fortune has been ascribed to the Mongol notion of khiimor', a Buddhist-influenced idea of fortune derived from the Tibetan rlung-rta (Swancutt in press and 2006a: 75-6, see also 82). Fortune has also been used as a gloss for khishig, which propagates people and livestock among Buryats, who also have khiimor' (Empson 2007: 113-7, see also 127-8). In my view, khiimor' and khishig are both bodily affects. However in this article, I focus on the link between khiimor' and games.

At the level of popular religion, present-day Mongols consider that Buddhist deities and/or shamanic spirits elevate the fortune (khiimor') of any given person (male or female) at their own discretion. Like the Tibetan notion of rlung-rta, the Mongol notion of khiimor':

is transmitted asymmetrically - the deities confer it at their discretion - that is, from a human perspective, [it is transmitted] unpredictably ... To invoke rlung-rta as the explanation for a successful outcome is to direct attention to the divine, albeit temporary, election. Rlung-rta suggests a relationship between the deities and humans which obviates a preoccupation with systematic hierarchical ascent (Calkowski 1993: 32).

Fortune, then may increase at the very moment when its increase is most necessary, possibly subverting hierarchy in the process. Typically, Mongols give two examples in support of this idea: (1) the case where a sudden influx of fortune prevents one person, out of a group of travellers, from being killed in an automobile accident and (2) the case where a sudden influx of fortune helps the underdog playing a game or sporting match (often a wrestling match) to beat his more skilled opponent. In the case of the car accident, the survivor was often unaware of being in just the right location to avoid death. But in games, heightened fortune allows a player to perceive what had previously been imperceptible to him -including the winning move which, ordinarily, only that player's more virtuosic opponent would have detected. This link between increased fortune and virtuosity may be due, in part, to the fact that Mongols and Siberians hold that 'jumping, dancing and wrestling are types of games which are supposed to please, entertain and delight spirits, that is, to render spirits favourable to humans', enticing those spirits to send influxes of fortune (Hamayon 1995: 5). Thus fortune and virtuosity collectively facilitate shifts in perspective which, particularly in games, overturn hierarchical relations.

In light of this, Inner Asia affords a fantastic breeding ground for what I propose to call 'Mongolian perspectivism'. This is a regionally specific model of perspectivism, applicable to any Mongol group, and drawn up for the purpose of this volume. I anticipate, however, that the ideas in this model could be applied back onto Viveiros de Castro's perspectivism, expanding his existing theory (more on this later). Pedersen has already characterised the cosmology of Inner Asian 'animism' as a 'Swiss Cheese' in which the same interior spiritual quality 
is only sometimes ascribed to all subjects (2001: 415-6). Similarly, I approach perspectivism in terms of when it applies to various Mongol settings (e.g. when game players are in fortune or have the necessary virtuosity to perceive winning moves). Taking the argument further, I show that Mongols ascribe varying degrees of bodily affects to all beings (spirits, humans and animals) at the intraspecies level. Using virtuosity and fortune, Mongols may also conflate their human subjectivity with that of an animal dependant in a kind of interspecies perspectivism, to which I now turn.

\section{MONGOLIAN PERSPECTIVISM}

Here I present Mongolian cosmological notions about the ownership of land and animals. Mongol ownership claims are not only critical to grasping more general ideas about Mongol subjectivity. They also allow gaming virtuosi to simultaneously shift perspective at the intra-species level (adopting the virtuoso's point of view) and at the interspecies level (adopting animal affects). These points underpin my argument, developed in later sections, that Mongol game players use their virtuosity to swap perspectives with other players, don animal affects and perceive the winning moves.

A cosmological system of land tenure regulates Mongol spirit, human and animal relations. At the top of this hierarchy are nature spirits, called 'savdag' when they dwell in mountains and 'shivdeg' when they dwell in waters. Nature spirits are frequently lords (ezen) over specific ranges in the landscape and wild animals, who take the form of Buddhist deities (burkhan) and pre-Buddhist spirits co-opted by Buddhism (Bawden 1994). In exchange for proper sacrifices, nature spirits throughout the Inner Asian region allow people to conduct pastoral and other activities in human inhabited areas (khünii suudag gazar), making pastures plentiful and protecting them from natural disasters, while also allowing people to occasionally enter wild terrain (zelüüd gazar) and hunt wild animals (Humphrey with Onon 1996: 149-60; Sneath 2001: 237-49; Bawden 1994: 1-5; Karmay 1998: 426-35; Berounský \& Slobodník 2003: 269-70; Birtalan 1998: 199-200). Along with other Buddhist deities and shamanic ancestral spirits (ongon), nature spirits monitor people's behaviour, punishing anyone whom they observe perpetrating unethical acts (e.g. polluting the landscape). Punishments include inflicting illnesses such as the nature spirit's poison-curse (lusin khorlol) or making environmental conditions difficult for pastoralism. People are thus subordinate to different kinds of spirits, who regulate landholdings and implement moral sanctions. At the same time, people are granted exclusive control over livestock and other domestic animal dependants, such as dogs.

Clear hierarchies and animal ownership claims therefore promote species divisions between Mongol humans, spirits and animals. Occasionally, though, Mongols conflate the subjectivity of people or spirits with the subjectivity of their animal dependants. For instance, Mongols allow that spirits and people own 
animals which can simultaneously be: (1) subjects unto themselves (beings with their own affects and spiritual qualities) and (2) the bodily affects of their owners, i.e. a part of their owners' distributed personhood or 'spirithood', in the sense given by Wagner (1991), Strathern (1988) and Gell (1998). These animals may switch between assuming their own interior spiritual qualities and those of their owners, oscillating between crossing and not-crossing the inter-species divide, like Willerslev's Siberian hunters (2004: 630). Thus, Mongols sometimes find that wild animals harbour within themselves a nature spirit or 'a human (spirit) purpose ... [Although] if you met a wild animal, normally it would not even occur to you if it were a spirit or not. Animals are just animals. But you might have such an idea if an animal suddenly behaved strangely and at the same time there was something wrong, if you had inexplicable illness or bad luck' (Humphrey with Onon 1996: 102). Similarly, Buryats coax domestic animals into being both sacrificial animals in shamanic ceremonies (subjects unto themselves) and human property (human bodily affects) being prepared for transference to the spirit world. Animals are not properly sacrificed unless they adopt the human purpose - and perspective - of willingly giving themselves up to the spirits. To this end, Buryats first make sacrificial animals drink from a cup filled with milk and juniper incense (drinking with a human bodily affect). Then Buryats place this cup atop the animal's back (making it use the animal affect of bearing a load), and cause the animal to walk in circles, moving clockwise, until the cup drops to the ground - a sign that the animal has agreed to be sacrificed.

The Buryat Mongols I knew in Bayandun, Dornod Province, Mongolia (see note 1 for fieldwork dates) even conflate subjectivity in the case of personal effects. Nature spirits, they said, own real wild animals, spirit-animals and spiritpersonal-effects, such as the pots and pans that a spirit uses for its own cultural life of cooking, cleaning, etc. (Swancutt 2003: 56-7; see also Swancutt in press). All of these possessions comprise elements of a nature spirit's distributed spirithood, such that Buryats consider them to be 'nature spirity' (savdagtai), or literally, endowed 'with nature spirit'. Like nature spirits (and shamanic spirits), both spirit-animals and spirit-personal-effects are invisible to laypersons, although they may be visible to shamans. Buryats conceive of nature spirits as riding through their domains atop their spirit-animals, with their spirit-personaleffects strapped to their saddles. ${ }^{3}$ Typically, nature spirits take a human shape (male or female, old or young, beautiful or ugly), bearing with them a retinue of real and spirit-animals plus spirit-personal-effects (all of which are spirit affects), as they move through their domains. However, nature spirits occasionally lose their spirit-animals, when falling from their mounts and failing to reclaim them. And nature spirits sometimes fail to notice that one of their personal effects fell from where it had been strapped to their mount. Gradually, as spirit-animals and spirit-personal-effects go unclaimed by their owners, they metamorphose from a nature spirit's affect into an independent nature spirit. Lost spirit-animals and spirit-personal-effects do not take a human shape; they retain their outward appearance. But because they had originally been nature spirity, they also retain - 
at an ontological level - the subjectivity of a nature spirit (i.e. their interior spiritual quality and bodily affects continue to be nature spirity). These 'offshoot' nature spirits do not usually become lords over a given terrain, but remain less powerful than their former owners, as 'novices' in the nature spirit realm.

Two modes of perspectivism are thus made possible by Mongol notions of ownership. First, the Mongol notion that animals and personal effects qualify as the bodily affects of their owners is an example of intra-species perspectivism (animals and personal effects are either human elements within their owners' distributed personhood or spirit elements within their owners' distributed spirithood). Second, the Mongol notion that animals and personal effects are subjects unto themselves, which happen to be owned by people or spirits, makes possible interspecies perspectivism (e.g. Buryat animals must be coaxed into adopting a human viewpoint before they are sacrificed). Mongols switch between these two kinds of perspectivism on the basis of their bodily affects, and not because they assume a relativistic outlook. In Stag, for instance, players shift perspective at the intra-species level when adopting the animal reflexes (or affects) of dogs, which as their animal dependants, are extensions of their personhood. Alternatively, players shift perspective at the interspecies level when acquiring the animal reflexes of deer which, as wild animals owned by nature spirits, are never properly extensions of human personhood. Players thus deploy a 'dual perspectival capacity' which, at present, distinguishes Mongolian perspectivism from Amazonian perspectivism (more on this below). To make this concrete, we will now consider how Mongols shift perspectives in the game of Stag.

\section{IT'S A DEER EAT DOG WORLD}

'The Stag' (Buga Jiregee) is a Mongol game akin to draughts, or checkers, and is typically played by two opponents (see Figure 2). There are numerous variations on the layout of the game (Tömör \& Altan 2002: 165-95), which is popular among Mongols living in China, but in Züün Sum people use a layout with thirtyfive possible positions in which a piece can land. The triangle at one end of the layout is called the rich ravine (bayan khorgo) and the diamond at the other end is called the poor ravine (yaduu khorgo), while the central rectangle is referred to as the steppe (tal). People in Züün Sum specifically regard the ravine as a natural channel (Chinese: gouhe) that has water in it and runs along the side of a steep cliff or between two mountains. Ravines may be visited by people who take their animals there to graze, but they are not inhabited by people. Instead, nature spirits in Züün Sum are imagined to reside in watery places such as ravines (as 'shivdeg', spirits of the waters). Züün Sum's own nature spirit, whom the local monastery caretaker identified by the Buddhist name of Seteve Choijin (no one else in Züün Sum knows the god's name), lives in a small bubbling spring (bulaga). This spring is located atop the mountain called Tsagaan Ovoo (a thirty minute drive from the district centre), where annual sacrifices are made to the 
spirit. By contrast, the steppe is associated with human inhabited terrain, which is regularly managed by herdsmen (malin ezen). Large numbers of people must make sacrifices to one nature spirit in order to use the steppelands, rendering the hierarchy between spirit and human lords disproportionately in the nature spirit's favour. In Züün Sum, for instance, there is one nature spirit, but his dominion covers a region in which roughly 3,000 people reside.

This hierarchy between nature spirits, humans and the animals they look after is reflected in the basic opposition that Stag sets up. One player assumes the role of the stag, a wild animal that can live in ravines. People in Züün Sum consider the stag to be the steed of the nature spirit or of the deity called the 'Heavenly Khan' (tengeriin khan) in storybook legends. They therefore attribute the stag

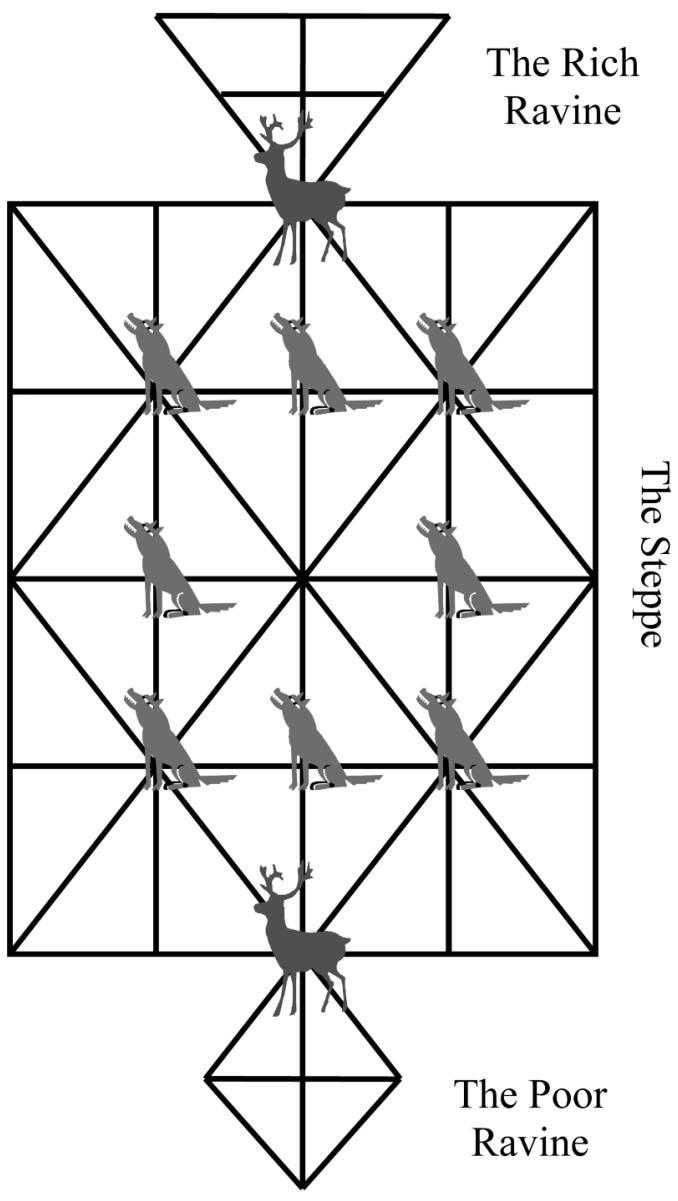

FIGURE 2. Initial layout for 'The Stag'. 
with great fortune (ikh khiimortoi). The stag is also revered (khündetgeltei) for being a wild animal with antlers that have medicinal properties for the blood. Against this is the player who assumes the role of the dog, a domestic animal that watches livestock on behalf of people and which also has great fortune (albeit, less than the stag), because it is the only animal that can be reborn as a human. ${ }^{4}$

I should say that some people in the district centre of Züün Sum consider the match to be between deer and sheep (not dogs), making the spirit-wild and human-domesticated contest for grazing lands more direct. This view is consonant with how Stag is recorded in the district's locally produced book about itself where, people in Züün Sum suspect, the authors present the game according to how they imagine it to have been played by Mongols at large (Züügelii \& Bayan 1997: 286-7). But herdsmen in Züün Sum's countryside hold that the game is between deer and dogs, and district centre residents usually defer to that view.

Unlike in draughts, the two players of Stag are equipped with different numbers of pawns and make use of different strategies. At no point in the game can either player opt not to move. Whoever takes on the role of the stag only has two pieces, which at the start of play are situated at the points where the ravines adjoin the steppe. This parallels the real life scenario where stags tend to be fewer in number than domesticated animals, just as there are fewer nature spirits than there are people. To compensate for their low number, the stags can 'jump' and 'eat' (idne), or eliminate, the dogs from play. ${ }^{5}$ By contrast, whoever is the dog starts out with eight pieces on the board, and is further equipped with another sixteen pieces (for a total of twenty-four) which can be added, one move at a time, to the game. The dogs cannot jump and eliminate the deer. This reflects the real life situation where dogs have to work in droves, blocking animals, such as deer, from moving point by point within a fixed terrain (where only their masters' livestock should graze). Altogether, then, Stag presents us with a deer eat dog world, where the object of the game for the deer is to eliminate as many dogs as possible, maintaining full range of movement along the ravines and steppelands. By contrast, the dogs' aim is to trap the deer anywhere on the game's layout, holding them under their watchful guard (khamgaalal; see Figure 3).

Children in Züün Sum are usually around ten or twelve years old when they start to learn Stag from other children at school. Deed Mongols compare the strategic demands of the game with those found in Western chess and Mongol chess (Mongol shatar), which is in fact the Chinese game Xiangqi. Competitions at the larger Mongol national sports festivals (naadam) that are held in Qinghai's cities and rural districts during summertime sometimes sponsor official matches in the game. In summer 2005, Züün Sum's champion reached the third round in an official competition in the city of Golmud (Chinese: Geermushi). His view on the relation between games and fortune, quoted at the start of this article, demonstrates that for a champion, all gaming strategies are transparent. Indeed, the strategies are so transparent to this champion, who is a self-professed 'unreligious' person (shaashin shütdeggüi khün), that he denies the game would be influenced by sudden influxes of fortune. However, other players in Züün Sum 


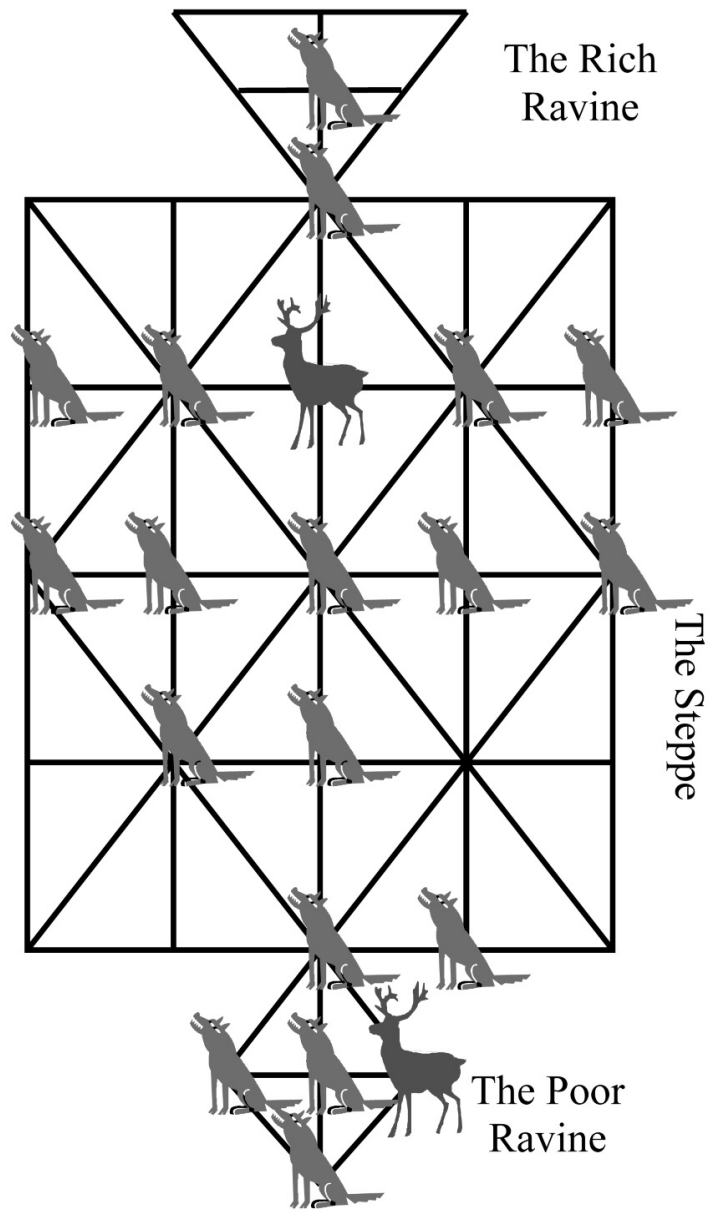

FIGURE 3. One possible game outcome, in which the stags are trapped.

who do not readily perceive the winning moves consider that influxes of fortune help underdogs to win a game.

\section{LEARNING TO PERCEIVE THE ALEATORY POINT}

Each move in the game of Stag, like in chess, yields a new configuration of the gaming pieces. Some configurations allow players to make a winning move, or a winning series of moves. Deleuze calls these configurations the game's 'aleatory points' (1990: 59-60). Building on Deleuze's idea, I propose that aleatory points are not just configurations on the game board, but viewpoints or perspectives in 
their own right which may overwhelm players, causing them to adopt the animal reflexes of deer (evading predators) or dogs (corralling intruders). Namjildorj discusses strategies in Stag which are appropriate to specific gaming configurations: 'tegnee', where a player blocks his opponent's manoeuvrability, corralling him with a horizontal or diagonal line of pawns, 'chikhen chagnaa' where a player pricks up his ears, listening intently to gauge his opponent's moves and 'shor' where a player pierces his opponent - as with a barbeque skewer (shorlogo) - to secure a winning move (1963: 131-3). Note that all three of Namjildorj's strategies appear to draw upon animal reflexes (in the case of shor, piercing an opponent could refer to the dog's final corralling move or the deer's elimination of a dog). Aleatory points, and the strategies they entail, are transparent to virtuosi, who regularly use them to adopt the affects necessary to a win. But less experienced players only perceive aleatory points when exchanging perspectives with a better player or receiving an influx of fortune.

I am not trying to suggest that Mongols carry out esoteric role-play in the game of Stag, impersonating deer or dogs through perspectival shifts that occur only at the level of emotions (rather than at the level of affects). People in Züün Sum regularly insisted to me that when they play Stag, they do not pretend to be deer or dogs but focus on the strategic demands of the game (I discuss the risk of impersonating animals below). And no one I met in Züün Sum could say why the game sets dogs against deer. Still, since Stag sets up a competition between the spirit-wild and human-domesticated animal worlds - through the gaming board layout, the kinds of moves that different players make and the numbers of pieces they are assigned - I propose that the strategic demands to which Züün Sum people refer force players to adopt, alternately, deer or dog affects. Virtuosity at Stag would, then, require adopting the real-life survival strategies of dogs and deer, such that players simultaneously shift perspective at the levels of human (virtuoso vs. novice) affects and animal (deer vs. dog) affects. What combination of affects would that entail?

In real life, there are greater numbers of dogs than deer on the steppe. The person playing as the dog therefore initially places his pieces on the gaming board's 'steppe'. As Mongols in Züün Sum point out, their dogs are actually trained to corral and trap animals in place, rather than killing intruders straightaway. Moreover, dogs usually corral animals in conjunction with people on horseback. Given this, I argue that good players of Stag use their virtuosity affect to gauge, from how the pawns are arranged on the gaming board, the dog's tactic for corralling. Players may perceive aleatory points, which prompt them to undergo an intra-species shift in perspective (since dogs may be extensions of their owner's personhood, corralling animals together with their owners). Or players may undertake an interspecies shift in perspective (adopting the affects of dogs who corral animals on their own). Conversely, in real life, deer enter human terrain at places, such as ravines, where the wilderness and the steppe conjoin the very points on the gaming board where the person playing as the deer initially places his pawns. Real-life deer do not eliminate dogs from their terrain by 
'eating' them. But Mongols in Züün Sum point out that deer do jump when chased, thus leading dogs astray from the effort to corral them. Players of Stag, then, use their virtuosity affect to gauge, from the arrangement of the pawns, the deer's strategy for dodging predators (which allows them to 'pierce' [shor] and eliminate their opponents). Since Mongols do not regularly interact with deer, adopting deer affects always requires perceiving aleatory points, which induces an interspecies shift in perspective. Through this perspectival shift, players may simply adopt the animal reflexes of 'deer qua deer'. Alternatively, players may gain access to a nature spirity affect, because deer are extensions of the nature spirit's spirithood. Indeed, people in Züün Sum pointed out that many deer reside atop Tsagaan Ovoo, and are sustained by the freshwater spring in which their nature spirit resides.

The question, then, arises: is virtuosity in Stag a purely human affect? I argue that it is, since players acquire their virtuosity through the context of the game, which is played with other people. Moreover, players do not evidence the behaviour of people who have exclusively adopted animal affects (leaping about or coralling each other around the gaming board). Instead, players deploy the strategies that animals typically use to outmanoeuvre opponents in tandem with the human-trained ability to recognise aleatory viewpoints created by people on the surface of a gaming board. For Mongol game players, adopting different perspectives is thus less a matter of transcendence (ecstatically becoming an animal, sensu Eliade 1964: 182-4) and more a matter of transparency (perceiving the aleatory points, with animal reflexes). ${ }^{6}$ This dual perspectival shift, in which game players adopt human and animal (or even nature spirity) affects, fits squarely within the parameters of Mongolian perspectivism.

\section{DOUBLE MORALITY}

Often players of Stag follow a double morality which alters the parameters of the game, increasing the transparency of the aleatory points so that players may readily shift perspectives. Mongols actually use double morality as a pedagogical tool to increase players' virtuosity. But sometimes virtuosi help novices learn in order to accomplish something more than just winning, such as establishing a reputation for being a strategist, teacher or diplomat. The better player purportedly puts aside the effort to win and, allowing onlookers to watch him, teaches the underdog to perceive the aleatory points. Humphrey has shown that Mongol morality is built on the duality of exemplars and rules:

talking with Mongols I became aware that, while they of course do have rules, for them the more important arena of morality appears in the relation between persons and exemplars or precedents, that is in the general sphere of surtakhuun ['those things that have been taught']. The concern here is with the cultivation of the self as a moral subject in relation to individually chosen ideals. Morality in this sense 
is not simply the affirmation of existing cultural ways of life; there needs to be a social space for deliberation about ways of life, amid the pressures that circumscribe the instantiation of personal ideals (1997: 25; the bracketed translation is Humphrey's and appears earlier on the same page).

Games, comprised of exemplars and rules, afford an ideal space for self-cultivation and deliberating about ways of life. Recall that Mongols play games to train their minds and learn the art of war. Indeed, Züün Sum's champion of Stag is known for both his prowess in the game, which sets up a 'war' between deer and dogs, and for his success in leading the people of Züün Sum in a battle against the encroaching Chinese over grazing lands, around the time of the Cultural Revolution (B. Dulam pers. comm.). Although only in his mid-forties, this champion is highly respected as both an exemplary battle leader and game player. But people in Züün Sum also attribute wins to their fortune and industrious effort (charmailt; Chinese: nuli). Mongols acknowledge this double morality in games by pairing the jovial, flippant notion that 'a game is just a game' (ene zövkhön togloom) with the sober fear of transgressing hierarchy, expressed in the proverb that 'games are riddled with demons' (naadam chötgörtei). ${ }^{7}$ Indeed, Dulam has argued that people in Züün Sum assert their power most successfully when adopting subtler tactics which only transgress hierarchy indirectly (2006). Numerous people in Züün Sum - the champion, casual and occasional players of Stag - thus gave me a nervous or laughingly dismissive 'no' when I asked whether they might ever undertake human-spirit conflict, either directly or via their dogs and deer. But some people quietly told me that human-spirit conflict is hypothetically possible (in or outside of the game). These people then stressed that any conflict with the nature spirit, who makes their grazing lands and herds prosperous, would be too dangerous to undertake. Impersonating animal dependants when playing Stag was considered risky, and people preferred to characterise the game as one which requires strategy (or human virtuosity).

Mongols evidence double morality when downplaying competition in games, initially denying their skill (and competitive motives), then later revelling in their prowess - as did Züün Sum's champion at Stag when I first inquired about his skill in the game. This double morality is actually encouraged by the notion in Züün Sum that consistent wins are gained through upstanding morality (i.e. industry). Like virtuosity and fortune, morality is a bodily affect, not simply an emotion, manifest through active work effort. Game virtuosi, then, industriously help train the novice's mind by giving spoken corrections or, seeing the novice about to make a faulty move, forestalling him with warnings. Virtuosi also make 'leading' moves that help reveal aleatory points to novices, who in turn work to perceive them. I observed Züün Sum's champion use these techniques on several occasions, when playing with family members and friends. Taking their industry further, virtuosi occasionally subvert the gaming rules to help novices learn. When this happens, players approximate Deleuze's ideal game (1990: 58-60).

Deleuze defines the ideal game as a match between virtuosi who, in their 
every move, perceive an aleatory point and make a winning manoeuvre (1990: 60). Devoid of competition, the ideal game ceaselessly gives rise to victories and lasts indefinitely, in a linear mode of time that Deleuze calls the 'aion' (1990: 61). Because these gaming parameters are impossible to maintain, Deleuze argues that the ideal game exists only as an abstraction in the mind:

In it there is nothing but victories for those who know how to play, that is, how to affirm and ramify chance, instead of dividing it in order to dominate it, in order to wager, in order to win. This game, which can only exist in thought and which has no other result than the work of art, is also that by which thought and art are real and disturbing reality, morality, and the economy of the world (1990: 60; emphasis is in the original).

Accordingly, the notional existence of the ideal game makes it 'the reality of thought itself and the unconscious of pure thought' (Deleuze 1990: 60). The chess match that Luzhin plays in his mind - against his own perspective - is an example of the ideal game. Dull because it continually gives rise to victories, the ideal game is nonetheless also the wellspring of Luzhin's virtuosity. All ideal game moves are virtuosic and lead to victories (pre-empting players' motives to win). By contrast, real games afford the notion of chance, of an opposition between winner and loser, and of a morality which dictates that inequalities between players should be managed in particular ways.

The final point about managing morality is critical. It suggests why Deleuze's anti-hierarchical ideal game, in which players always perceive aleatory points and achieve victories, can be regarded as the model - the reference point or 'signifier' - for real games. Mongols often use double morality as a means of making real games approximate ideal games. When virtuosi play Stag in its nearideal form, they alternate between opposing novices in order to win (restricting novices' manoeuvrability) and assuming a cavalier approach to reciprocal learning ('generously' revealing aleatory points to novices, in moves that actually display the virtuoso's prowess). For instance, if the novice finds that he is 'stumped', or unable to perceive how to progress further in Stag, the industrious virtuoso may - allowing the pieces to remain where they are on the gaming board - exchange his position for that of the novice. Züün Sum's champion frequently swapped roles when playing with his younger sister, rotating the gaming board by 180 degrees to present her with his orientation to the pawns. When the virtuoso swaps his advantageous position for the novice's disadvantageous one, he exchanges virtuosic affects and a certain win for novice affects and a morally upright reputation. This exchange extends the play beyond its natural course, allowing the novice a victorious move (he or she suddenly gains access to the virtuoso's position), despite that novice's previous failures to perceive the aleatory points. Players' roles may be swapped indefinitely in cases where novices are continually stumped.

Alternatively, if a novice unwittingly makes a compromising move that sacrifices one of his pawns, he may insist on redoing that move. The virtuoso may 
agree, on the condition that he also can rescind his previous move - the very move which precipitated the novice's blunder. From there, novice and virtuoso backtrack through any number of previous moves, until both players agree to reenter the game at the point of a specific move. Sometimes players rescind moves in such a flurry that they are unsure about the accuracy of what they had done. Players may quarrel about how the moves were rescinded (evidencing their competitive motives) until agreeing to casually choose where to start again. I observed numerous matches where players retracted moves.

Adapting the game of Stag into a near-ideal form has an impact on the perspectival shifts that players can make. First, in near-ideal games virtuosi make efforts to render aleatory points transparent to their opponents. Second, where players of Stag swap roles (rotating the board between them and taking on the opponent's role of deer or dog), they exchange not only novice and virtuosi affects but also animal (deer and dog) affects. Finally, when players rescind moves, they gain the opportunity to repeat their previous moves while searching for the aleatory points that had originally been opaque to them.

\section{COULD VIRTUOSITY BE THE ONTOLOGICAL ENDPOINT TO PERSPECTIVISM?}

Whether virtuosi and novices exchange advantageous for disadvantageous positions, rescind moves, or strictly follow the parameters of the real game, they progressively refine their virtuosity. This article has shown that virtuosity is an affect which game players hold to varying degrees and exchange with one another during the course of a game. In exchanging various bodily affects, players alter their subjectivity. For instance, players of Stag simultaneously draw upon human (virtuoso or novice), animal (deer or dog) and fortune (high or low fortune) affects. Players combine these affects, and thus conflate their subjectivity with that of other players (intra-species perspectivism) and of animal dependants (interspecies perspectivism). However, they do not simply retain these bundles of affects in a static way. Instead they exchange their perspectives over the course of one or more games. Each of these exchanges causes a player's subjectivity to fluctuate along an ontological spiral, which culminates when players irreversibly refine their virtuosity affect. Sometimes several games elapse before a player manages to change his or her virtuosity affect (as shown in Figure 1). On other occasions, players progress through numerous ontological spirals during a single game, increasing their virtuosity affect several times over.

Anthropological studies of perspectivism have emphasised that shamans and hunters broach dangerous metamorphoses when shifting perspectives at the interspecies level (Viveiros de Castro 2004: 468; Willerslev 2004: 647). However, Mongols also shift perspectives in safe settings, such as the pedagogy of games, which encourages irreversible metamorphoses at the intra-species level (making ordinary people into virtuosi) while allowing players partial and 
reversible metamorphoses at the interspecies level (players temporarily conflate their subjectivity with that of their animal dependants). The question, then, arises: could Viveiros de Castro's theory of perspectivism be revised in light of how people train to become virtuosi, capable of shifting perspectives at the intraspecies and interspecies levels? In his contribution to this volume, Viveiros de Castro shows that Amazonian shamans regularly use their virtuosity affect as the means of 'seeking out' and perceiving illumination:

the perceptive experience of luminous intensity is sought out by the shaman, not merely suffered (as a side-effect of drugs taken for other purposes), which strongly suggests that it possesses a conceptual value in itself (Viveiros de Castro this volume).

The shaman's effort to perceive luminous intensity shows that Amazonians actively induce intra-species perspectivism (making for differently skilled shamans). It seems possible that Amazonian shamans could refine their virtuosity affect each time they seek out illumination. However, it has not yet been shown whether Amazonians, like Mongols, hold that bodily affects (e.g. low fortune) and interior spiritual qualities (e.g. souls or spirits) are mutually influential (triggering each other's presence or absence). Nor has there been Amazonian evidence for people conflating humans or spirits with their animal dependants. We have seen that Mongol game players may conflate their (human) virtuosity affect with animal affects, giving rise to both intra-species and interspecies perspectivism. Demonstrating the extent to which interior spiritual qualities, bodily affects and subjectivity are conflated in Amazonia would allow us to confirm which modes of perspectivism are common to both regions. It would also give further evidence for addressing general questions about the nature of subjectivity, which ultimately underpin perspectivism.

Anthropologists now commonly say that 'you can find perspectivism anywhere, if you look hard enough'. There is a simple truth behind this. Fluctuations in bodily affects occur everywhere, whether induced directly through pedagogical training or received indirectly through mediums such as fortune. These fluctuations level out differences between subjects, helping novices adopt a virtuosic perspective and vice versa. This is not to say that everyone is a potential virtuoso. But it does suggest that perspectivism is a more fluid theory than has been perceived up to this point, a theory which encourages active efforts to shift subjectivity within and between species. If we refine our understanding of Viveiros de Castro's perspectivism accordingly, then the distinction between it and Mongolian perspectivism may soon be made redundant. 


\section{NOTES}

I am grateful for comments made on earlier seminar versions presented at the Institute of Social and Cultural Anthropology at the University of Oxford, the Mongolia and Inner Asia Studies Unit at the University of Cambridge and the Magic Circle, an anthropology of religion reading group at the University of Cambridge. A special thanks to Bumochir Dulam for comments on an earlier draft, and for his insights into the people and cosmology of Züün Sum. I also thank Giovanni Da Col for insightful conversations on virtuosity and fortune, and thank the anonymous reviewers for Inner Asia. Fieldwork for this article was made possible by a British Academy Research Grant Award (RG 43012).

${ }^{1}$ While I collected ethnography on games during my 2005 research among Deed Mongols in Züün Sum, this article also draws upon my Ph.D. fieldwork among Buryat Mongols in Bayandun, Dornod Province, north-east Mongolia and Baruun Sum, Evenk Banner, Inner Mongolia Autonomous Region, China from 1999 to 2000, as well as one month's fieldwork carried out in Bayandun in summer 2004.

${ }^{2} \mathrm{I}$ am grateful to Andrew Moutu for calling this parallel with Bateson to my attention.

${ }^{3}$ Mongol iconography depicts spirits riding atop their spirit mounts, as with the Buddhist deity whom Buryats call 'Choijiloo', shown riding atop a blue bull, and the Buryat shamanic blacksmith deity called 'Damjin Dorlig', shown riding atop a red goat.

${ }^{4}$ Many people in Züün Sum had heard of the notion, widespread among Mongols, that dogs can be reborn as people, but laughed at the idea, saying they did not believe it because they were 'unreligious people' (shaashin shütdeggüi khün). Qinghai Province is strongly influenced by the official disfavour of 'superstition' (Chinese: mixin).

${ }^{5}$ No one in Züün Sum knew why the metaphor of 'eating' the dogs was used, except to say that this is the ordinary expression used for eliminating pawns from a game. People pointed out that, in the game of Stag and in real life, no deer eats a dog.

'In two other Deed Mongol children's games that I learned about in Züün Sum, called 'Blind Mother' (Sokhor Eej) and 'The Grey Ram' (Bor Ireg), children take on the roles of sheep, wolves, herdsmen and a poor man, crossing the interspecies divide using a similar, conflated assemblage of human virtuosity and animal reflexes.

${ }^{7}$ I am grateful to Hürelbaatar for drawing this proverb to my attention.

\section{REFERENCES}

Bateson, G. 1936. Structural analysis of the Wau-laua relationship, in Naven: a survey of the problems suggested by a composite picture of the culture of a New Guinea tribe drawn from three points of view: 74-85. Cambridge: Cambridge University Press.

Bawden, C. 1994. Two Mongol texts concerning obo-worship, in Confronting the supernatural: Mongolian traditional ways and means: 1-19. Wiesbaden: Harrassowitz Verlag.

Berounský, D. \& Slobodník, M. 2003. The noble mountaineer: an account of la btsas festival in Gengya villages of Amdo, Archiv Orientální: quarterly journal of African and Asian studies. 71: 263-84.

Birtalan, Á. 1998. Typology of stone cairn obos (preliminary report, based on Mongolian fieldwork material collected in 1991-1995), in A-M. Blondeau (ed.). Tibetan mountain deities, their cults and representations: 199-210. Wien: Verlag der Österreichischen Akademie der Wissenschaften. 
Calkowski, M. 1993. Contesting hierarchy: on gambling as an authoritative resource in Tibetan refugee society, in Anthropology of Tibet and the Himalaya: 30-8. Zurich: Ethnological Museum of the University of Zurich.

Deleuze, G. 1990. Tenth series of the ideal game, in The logic of sense. M. Lester with C. Stivale (trans.): 58-65. London: Athlone Press.

Dulam, B-O. 2006. Respect and power without resistance: investigations of interpersonal relations among the Deed Mongols. Ph.D. Thesis, University of Cambridge.

Eliade, M. 1964. Shamanism in Central and North Asia: I. Celestial ascents. Descents to the underworld, in W. Trask (trans.). Shamanism: archaic techniques of ecstasy: $181-214$.

Empson, R. 2007. Separating and containing people and things in Mongolia, in A. Henare, M. Holbraad and S. Wastell (eds.), Thinking through things: theorising artefacts ethnographically: 113-40. London: Routledge.

Galdanova, G.R. 1987. Dolamaistskiye Verovaniya Buryat (Pre-lamaist beliefs of the Buryat). Novosibirsk: Nauka.

Gell, A. 1998. Art and agency: an anthropological theory. Oxford: Clarendon Press.

Hamayon, R. 1995. Why do ritual games please shamanic spirits and displease transcendent gods? An essay on 'playing' as a basic type of ritual behaviour, in, Louis H. Jordan Lectures in Comparative Religion. London: SOAS.

Hamayon, R. 1996. Shamanism in Siberia: from partnership in supernature to counterpower in society, in N. Thomas and C. Humphrey (ed.). Shamanism, history and the state: 76-89. Ann Arbor (MI): University of Michigan Press.

Højer, L. 2004. Dangerous communications: enmity, suspense and integration in post socialist Northern Mongolia Ph.D. Thesis, University of Cambridge.

Hugh-Jones, S. 2004. Chair comments in discussion for Philippe Descola's Senior Seminar at the Department of Social Anthropology, University of Cambridge (13 February 2004). http: //www.dspace.cam.ac.uk/bitstream/1810/1475/2/ descola2.mp4

Humphrey, C. 1997. Exemplars and rules: aspects of the discourse of moralities in Mongolia, in S. Howell (ed.), The ethnography of moralities: 25-47. London: Routledge.

Humphrey, C. with Onon, U. 1996. Shamans and elders: experience, knowledge and power among the Daur Mongols. Oxford: Clarendon Press.

Karmay, S. 1998. The arrow and the spindle: studies in history, myths, rituals and beliefs in Tibet. Kathmandu: Mandala Book Point.

Mikhailov, T.M. 1987. Buryatskii shamanizm: istoriya, struktura i sotsial'nyye funktsii (Buryat Shamanism: history, structure and social functions). Novosibirsk: Nauka.

Nabokov, V. 2000 [1964]. The Luzhin Defense. M. Scammell in collaboration with V. Nabokov (trans.). London: Penguin Books.

N. Namjildorj. 1963. Mongolin (Khölögt) Togloom (Mongolian (Board) Games). Ulaanbaatar: Ardin Tsergiin Khevlekh.

Pedersen, M. 2007. Talismans of thought: shamanist ontologies and extended cognition in northern Mongolia, in A. Henare, M. Holbraad \& S. Wastell (ed.), Thinking through things: theorising artefacts ethnographically: 141-66. London: Routledge. 2001. Totemism, animism and north Asian indigenous ontologies, The Journal of the Royal Anthropological Institute. (N.S.). 7(3): 411-27.

Pedersen, M. \& Højer, L. (forthcoming). Lost in transition. Fuzzy property and soul loss in Ulaanbaatar, Ethnos. 
Sneath, D. 2000. Changing Inner Mongolia: pastoral Mongolian society and the Chinese state. Oxford: Oxford University Press.

Strathern, M. 1988. The gender of the gift: problems with women and problems with society in Melanesia. Berkeley and Los Angeles (CA): University of California Press.

Swancutt, K. (in press). Fortune and the cursed: the sliding scale of time in Mongolian divination. Berghahn Books.

2006. Representational vs. conjectural divination: innovating out of nothing in Mongolia, The Journal of the Royal Anthropological Institute. 12(2): 331-53.

2006a. Fortuna, sorti i destí a Mongòlia (Fortune, luck and fate in Mongolia), Revista d'etnologia de Catalunya. 28: 70-82.

2003. Magic works: divination, causation and witcheraft in north-east Mongolia and China. Ph.D. thesis, University of Cambridge.

Tömör \& Altan (ed.). 2002. Mongol Ulamjilat Naadam (Deed) (Mongolian Traditional Games (Volume 1)). Beijing: Minzu chubanshe.

Viveiros de Castro, E. 2004. Exchanging perspectives: the transformation of objects into subjects in Amerindian ontologies, Common Knowledge. 10(3): 463-84.

1998. Cosmological deixis and Amerindian perspectivism, The Journal of the Royal Anthropological Institute. 4(3): 469-88.

1998a. Cosmological perspectivism in Amazonia and elsewhere. General Lectures, Department of Social Anthropology, University of Cambridge (17 February - 10 March 1998).

Wagner, R. 1991. The fractal person, in M. Godelier \& M. Strathern. (ed.). Big men and great men: personifications of power in Melanesia. Cambridge: Cambridge University Press.

Willerslev, R. 2004. Not animal, not not-animal: hunting and empathetic knowledge among the Siberian Yukaghirs, The Journal of the Royal Anthropological Institute. (N.S.). 10(3): 629-52.

Züügelii (Chinese: Zhelai) \& Bayan ('Bayar', or Chinese: Bayi) (ed.). 1997. Deed Mongol Zü̈̈n Khushuuni Üilber (Practices of the Deed Mongols in Züün Banner). Inner Mongolia: Nei Menggu shaonian ertong chubanshe. 
